\title{
INVESTMENT SYSTEM FOR RENEWABLES OBJECTS USE GENERATING
}

\author{
Pavel Z. Ivanishin \\ Kazan Federal University, (Russia). \\ E-mail: Ssv@ores.su ORCID: https:// orcid.org/0000-0003-3833-1465 \\ Elena Yu. Kovalkova \\ Kazan branch of Russian State University of Justice, (Russia). \\ E-mail: Info@ores.su ORCID: https:// orcid.org/0000-0002-1650-1921
} $\begin{array}{r}\text { Alexander N. Shpagonov } \\ \text { Kazan Federal University, (Russia). }\end{array}$
E-mail: shpagonovan@gmail.com ORCID: https:// orcid.org/0000-0003-4234-7638

Recepción: 11/12/2019 Aceptación: 21/01/2020 Publicación: 13/03/2020

\section{Gitación sugerida:}

Ivanshin, P., Kovalkova, E., y Shpagonov, A. (2020). Investment system for renewables objects use generating. 3C Tecnologiá. Glosas de innovación aplicadas a la pyme, 9(1), 47-59. http://doi.org/10.17993/3ctecno/2020.v9n1e33.47-59 


\section{ABSTRACT}

In this article single legal questions of investment into creating the objects of generation based on renewables are considered. The issues connected with lack of terminological unity in the regulations regulating this sphere are touched; the noncompetitive environment of realization of the relations under the contract of power delivery; the contract subject blurring, lack of the proprietary relations description evolving from RES owing to creating new objects of generation.

The relations system of investment for renewables use is considered as a complex of the legal means organized in the most consecutive way for creating objects of generation and obtaining by sellers the right for sale of electric energy and power in the wholesale market. In this regard, features of the parties and subject of the contract of power delivery were studied.

\section{KEYWORDS}

Investments into power industry, Subjects of the wholesale market, The regulator of the power industry market on the basis of RES use, Generation of electric energy on the basis of renewables use, Contract of power delivery, Subject of the contract about granting power. 


\section{INTRODUCTION}

Increase in power efficiency of power industry based on renewables use (further - RES) promotes involvement of innovative high technologies and the equipment in the power sphere and implementation of the international obligations of Russia for restriction of emissions of greenhouse gases. Investment into building of generation of electric energy on the basis of RES use is supposed by means of the contracts of power delivery signed by results of the closed competitions according to the development plan for renewables approved by the Government of the Russian Federation (The resolution of the Government of the Russian Federation of 15.04.2014 No. 321, 2014).

Meanwhile, the structure "The "Council for Organizing Efficient System of Trading at Wholesale and Retail Electricity and Capacity Market" non-profit partnership offered by Association (further NP Market Council) the standard contract of power delivery is represented very tangled what can not only complicate further control of its execution, but also in general reduce investment appeal of the offered project on creating generation on the basis of RES. First of all, it is shown in the contract subject blurring - discrepancy of the purpose for the sake of which the mechanism (investment) given right to the actual contents of the contract was developed, and also in absence in the contract of the instruction for the real rights arising on again created objects of generation including the land plots and buildings which are on them and constructions, and also infrastructure facilities (also communications are expensive).

According to a standard form of the contract on granting power (further - the contract on granting power, the PDM) (http://www.np-sr.ru) data contracts are signed concerning objects of generation (http:// digitalcommons.wcl.american.edu) for which any of the following circumstances - commissioning, certification (testing), obtaining by sellers the right for sale of electric energy and power in the wholesale market - arises after the conclusion of the agency contracts providing the conclusion of contracts on granting power. At the same time, attracts attention insufficiently worked competences of all participants of the considered relations. 


\section{METHODS}

The complex of methods was used (a method of induction and deduction, a method of the analysis and synthesis, an ascension method from abstract to concrete, a comparison method) that allowed to investigate with the greatest reliability difficult and multipurpose relations system of power delivery for investment into the generating objects of RES. The theoretical analysis of the regulatory base and right realizable practice allowed to consider the contract granting power as the mechanism of creating objects of generation in the sphere of RES. Analyzing the separate facts, grouping, systematizing them, we reveal in them the general and special.

The analysis is followed by synthesis that helped to get into essence of the studied system. The comparison method allowed defining distinctions or a community of the studied object with adjacent contractual categories (http://www.renewableenergyworld.com). The method of induction and deduction, in relation to a research allowed to pass from separate elements to formation of complete idea of power delivery as means of investment into the generating objects of RES and gave the chance to connect all communications and the relations and to draw partial conclusions.

\section{RESULTS AND DISCUSSION}

The analysis of relations system of investment for renewables use allows speaking about the special subject list of participants. The group of participants acts as the parties of the contract on granting power.

(1) As the buyer the participant of the wholesale market included in NP Market Council in the Register of subjects of the wholesale market which signed the Contract on accession always acts and carries out acquisition of power, including for own production needs and (or) for the subsequent sale, but anyway as the usual economic activity provided by the charter of the Buyer. 
The organization joins in the register of subjects of the wholesale market according to the decision of the supervisory board of NP Market Council. For obtaining this status several requirements are imposed on the participant:

- compliance of the power accepting and generating equipment to the quantitative characteristics applied in groups of points of delivery of electric energy and power;

- holding actions of technical character: on equipment of each point of delivery, the measuring instruments providing collecting, processing and transfer of commercial infrastructure of data of the commercial account to the organization; on the equipment the communication system providing transfer of the data to the system operator necessary for implementation of the centralized supervisory control within UES of Russia;

- coordination with the system operator and the organization of commercial infrastructure of group of points of delivery with which use the organization plans to participate in trade in electric energy and (or) power in the wholesale market.

Let's note that any participant of the wholesale market of electric energy (power) can act as buyers (URL: http:/ / www.np-sr.ru):

First, it is suppliers of electric energy and power - owners of the generating equipment. It agrees, to data of the register 101 participants among which there is, for example, PJSG Mosenergo, JSG Tatenergo, LLC Lukoil Kubanenergo, JSG SIBECO, LLG Vorkuta Combined Heat and Power Plants, LLC Ulyanovsk-Kogeneration (https://www.eia.gov), etc. are registered.

\section{Secondly, buyers of electric energy and power:}

From which the power marketing organizations, for example, such as to JSC Transservisenergo are separately distinguished, to JSC EK Vostok, JSG Atomsbyt, LLC Lukoil-powerservice, JSC Mosgorenergo, etc. (116 participants are registered). 
Large consumers, for example, PJSG Novolipetsk Steel, the Kazan PJSG Organichesky sintez, LLC LADA Izhevsky Avtomobilny Zavod, JSG Vodokanal, LLG Lenta, etc. (26 subjects are registered).

The guaranteeing suppliers, for example, JSC Pyatigorsk Electric Networks, JSG Lipetsk Energy Retail Company, PJSC Mosenergosbyt, LLC Zarinsk City Electric Supply Company, JSC Tatenergosbyt, etc. (99 participants are registered).

As the organization which is carrying out export-import transactions only one subject of PJSG Inter RAO UES is registered.

The territorial network organizations for implementation of functions of the guaranteeing supplier eight subjects are registered: PJSC IDGC of Volga, PJSC IDGC of the Northwest, PJSG IDGC of the North Caucasus, JSG IDGC of Ural, PJSG IDGG of Centre, PJSG IDGG of Centre \& Privolzhya, JSG Chechenenergo, PJSC IDGC of the South.

(2) The following participant - the Seller who is a subject of the wholesale market (are considered above), the participant of the address of electric energy and power in the wholesale market, is included by NP Market Council in the Register of subjects of the wholesale market and signed the Contract on accession to trade system of the wholesale market, and also is the subject of power industry which is carrying out activities for production and sale of power as provided by the existing charter of the Seller of usual economic activity.

It should be noted that on behalf of the Seller the Agency contract is acted by the agent under - Center of Financial Calculations Joint-stock company (further - CFG). At the same time CFG is the organization of commercial infrastructure in understanding of paragraph 9 of article 33 Federal Law "About Power Industry" and Contract on accession which according to the Contract on accession renders complex service in calculation of requirements and obligations of participants of the wholesale market, PJSC FGC UES and System operator. 
The infrastructure organizations act as other parties of the contract.

(3) "System Operator of the Unified Energy System" joint-stock company (further - the System operator). The system operator is according to the Federal Law "About Power Industry" (The federal law of 26.03.2003 N 35-FZ, 2003) a subject of supervisory control in power industry into which power implementation of the centralized round-the-clock and continuous management of the electrical power mode of a power supply system, and also control of timely and appropriate implementation of the investment program by the Seller (investment projects) of construction of the generating objects with which use trade in power in the wholesale market is carried out, including for ensuring power delivery with use of the objects of generation specified in the contract (further - control of implementation of the investment program), and also carrying out according to Rules of the wholesale market of certification of the generating equipment including which is again put into operation is included.

(4) "Trading System Administrator of the Wholesale Market of the Electric Power" joint-stock company (further - automatic telephone exchange).

The automatic telephone exchange according to paragraph 7 of article 33 Federal Law "About Power Industry" and the Contract on accession renders to subjects of the wholesale market, participants of the address of electric energy and power in the wholesale market the service in the organization of trade in the wholesale market connected with the conclusion and the organization of execution of transactions on the address of electric energy, power and other objects which address is allowed in the wholesale market and also carries out other functions of the Commercial operator of the wholesale market according to the rules of the wholesale market understood in that sense as it is established in the paragraph the seventh article 3 Federal Law "About Power Industry" (further - Rules of the wholesale market) and the Contract on accession including is given authority to determine the volume and the cost of the power bought under contracts on granting power. 
(5) "Council for Organizing Efficient System of Trading at Wholesale and Retail Electricity and Capacity Market Non-profit Partnership" association.

NP Market Council is Market Council in understanding of article 33 Federal Law "About Power Industry" into which power the statement of a form of the Contract on accession and changes to it, standard forms of the contracts providing implementation of trade in the wholesale market with electric energy, power which address is carried out in the wholesale market, including control of observance of Rules of the wholesale market and regulations of the wholesale market by the Seller and the Buyer subjects of the wholesale market and the organizations of commercial and technological infrastructure (automatic telephone exchange, CFC, the System operator) is included.

Several problems allowed revealing studying of the regulatory base governing the relations on investment into construction of facilities of generation, the renewable sources of power industry functioning based on use (further RES).

First, it is the problems of terminological character connected with lack of uniform approach to designation, the contractual designs used for this purpose. So, by means of which contract is supposed to carry out financing of processes of creating generation of RES in different regulations can be called differently: contract of purchase and sale of power, contract of power delivery, contract on granting power (See also General terms and conditions for the supply of Energy). At the same time often these terms are considered as synonyms, alternating with each other, and being sometimes shared (The resolution of the Government of the Russian Federation of 28.05.2013 No. 449, 2013).

Meanwhile, from the point of view of approaches, traditional for the Russian civil law, the contract of delivery though is a kind of the contract of purchase and sale, nevertheless has the distinctive features connected with subject structure and the purpose of the conclusion. Besides, use from the point of view of etymology of the word "granting" does not reflect a being of the arising relations in the name of this type of contracts of the term "granting power": putting into operation of a new object of generation 
of the electric power on the basis of RES due to repayment of the power made to data of objects in the future.

It is represented that the used legal technology of rule-making has defective character as lack of unity in terms leads to difficulties of differentiation of adjacent contractual designs, to complexity of perception, and eventually, to decrease in trust to the most investment project.

In turn, the analysis of maintenance of the electric power of a standard form of the contract on providing the generation to the power of an object functioning on the basis of use of renewable sources of power industry as means of investment of construction of these objects developed by the regulator of the market allowed to reveal a number of the moments complicating not only perception of this contract, but also the most built model of the relations in general.

First, it concerns subject of the contract. So, according to item 2.1. The PDM the seller undertakes to begin in due time delivery and during all term established by the contract to deliver power, and the buyer undertakes to accept it and to pay. Meanwhile, the formulation of subject of the contract does not reflect its essence. As, power delivery is only means by means of which financing of again created object of generation of RES is carried out. The purpose of the conclusion of a similar contractual design creation or modernization of an object of generation - is indistinct in the text of the contract and looks through only in some points. In particular: in item 1.10. The PDM is mentioned that the person who assumed liabilities on construction and/or modernization of an object of generation assumes liabilities to agree on the concrete list of works with the regulator (NP Market Council); according to item 3.3. it is provided that the period of power delivery of each object of generation terminates the last date of which end of 10-year term from start date of execution of the obligation for power delivery of this object of generation is the share; in item 14.5 in a context for delay of execution of the obligation on deliveries of power, regarding assignment the person who assumed liabilities on construction and/or modernization of a duty to send to the regulator the name and planned dates of commissioning of the objects of generation specified concerning which the delay of the beginning of performance of 
obligations on power delivery is allowed, with application of documents, proving the specified planned dates of input of objects of generation; in item 15.1. Regarding regulation of the relations on transfer of rights of duties it is specified by the PDM that for the purpose of application of the rules established in the present section is understood as object of generation as the object of generation put into operation and certified (tested) System operator object of generation concerning which the right of sale of its power in the wholesale market is acquired not finished by construction and (or) not put into operation and (or) not tested concerning which the specified right is not acquired.

It would be desirable to note that in the analysis of this contract total absence in it of the conditions regulating the real rights for again created objects of generation of RES is special surprising. In offered by the regulator of the PDM to the matter only one norm reflecting a possibility of the person which assumed obligation for creating this object of generation to make alienation by sale of the created or created object (item 15.1 is devoted. contracts). Meanwhile, it is represented that similar provisions of the contract are not only not fair, but also not based on requirements of the law. As financing of construction of the created object of generation is carried out not at the expense of available funds of the buyer, and due to inclusion of the investment expenses made by it in the price for end users. The most amazing that on the created object of generation there are no real rights, not only the buyer has capacities, but also at the state which in fact and acts as the customer of process on increase in efficiency of a power system and works in public interests.

\section{SUMMARY}

The relations system of investment for renewables use is considered as a complex of the legal funds allocated for creating objects of generation for increase in power efficiency of power industry. The contract on granting power acts as the main means of this system. At the same time, the analysis of its conditions revealed the following problems: 1) lack of terminological unity in standard regulation; 2) insufficiently thought over competences of participants of the adjustable relations; 3) not full compliance 
of subject of the contract to a being of the considered relations; 4) the question of pricing during creating new objects of generation of RES is represented disputable; 5) lack of the conditions regulating the real rights for again created objects of generation of RES (http://www.ucsusa .org).

\section{CONCLUSIONS}

Increase in efficiency of power industry based on RES use, is necessary for long-term and steady power supply of economic development of the Russian Federation, is directed to attraction of innovative technologies and the equipment in power branch and development of domestic production of the hitech generating equipment. Meanwhile, legislative regulation in the field demands essential amendments for increase in the competition, transparency and decrease in a corruption component.

\section{ACKNOWLEDGEMENTS}

The work is performed according to the Russian Government Program of Competitive Growth of Kazan Federal University.

\section{REFERENCES}

Gheng, T. H. (2005). Power, Authority and International Investment Law. American University International Review, 20(3), 465-520. https://digitalcommons.wcl.american.edu/auilr/vol20/iss3/1/

Federal law of 26.03.2003 N 35-FZ "About power industry". The Russian newspaper, 60.

Kaweske, J. (2015, December 11). Winds Favor Renewable Energy Sources. https://www. renewableenergyworld.com/2015/11/12/winds-favor-renewable-energy-sources/ 
Malamatenios, G. (2016). Renewable energy sources: Jobs created, skills required (and identified gaps), education and training. Renewable Energy and Enviromental Sustainability, 1(23). https://doi. org/10.1051/rees/2016038

NP Market Council. (2011). The resolution of the Government of the Russian Federation "About the approval of Rules of the wholesale market of electric energy and power and about introduction of amendments to some acts of the Government of the Russian Federation concerning the organization of functioning of the wholesale market of electric energy and power" of 27.12.2010 No. 1172. The Russian newspaper, 71. http://www.np-sr.ru/registers/marketsubject/index.htm

NP Market Council. (n.d.). Standard form of the contract on granting power. https://www.np-sr.ru/ru/ regulation/joining/standardcontracts/sf07/index.htm?.ssFolderId=1000065

Resolution of the Government of the Russian Federation of 15.04.2014 No. 321 (an edition of 31.03.2017) (2014). About the approval of the state program of the Russian Federation "Energy efficiency and development of power”. SZ Russian Federation, 18 (part III). - Art. 2167.

Resolution of the Government of the Russian Federation of 27.12.2010 No. 1172 "About the approval of Rules of the wholesale market of electric energy and power and about introduction of amendments to some acts of the Government of the Russian Federation concerning the organization of functioning of the wholesale market of electric energy and power". SZ Russian Federation, 23. - Art. 2909; 2011, 14. - Art. 1916.

Resolution of the Government of the Russian Federation of 28.05.2013 No. 449 "About the mechanism of stimulation of renewables use in the wholesale market of electric energy and power".

U.S. Energy Information Administration. (2020). What is U.S. electricity generation by energy source? https:/ / www.eia.gov/tools / faqs / faq.php?\%20id=427\&t=3;\%20https:/ / www.eia.gov/ energyexplained/index.cfm?\%20page=electricity_in_the_united_states 
